\title{
Changes of polybrominated diphenyl ether concentrations in ducks with background exposure level and time
}

\author{
Peng-Yan Liu ${ }^{\mathrm{a}}$, Xiao-Ran Chen ${ }^{\mathrm{a}, \mathrm{b}}$, Ya-Xian Zhao $^{\mathrm{b}}$, Yuan-Yuan Li $^{\mathrm{b}}$, Xiao-Fei Qin ${ }^{\mathrm{b}}$, Zhan-Fen Qin ${ }^{\mathrm{b}, *}$ \\ ${ }^{a}$ College of Chemistry and Environmental Science, Hebei University, Baoding, Hebei, China \\ ${ }^{\mathrm{b}}$ State Key Laboratory of Environmental Chemistry and Ecotoxicology, Research Center for Eco-environmental Sciences, Chinese Academy of Sciences, Beijing 100085, China
}

\section{H I G H L I G H T S}

- We conducted a semi-field experiment of ducks in an e-waste recycling site.

- $\sum$ PBDEs increased in fat with time, but fluctuated in other tissues with exposure level.

- High brominated DE levels increased with time but low brominated DE fluctuated in fat.

- High brominated DEs seem to have longer half-lives than low brominated DEs in fat.

\section{A R T I C L E I N F O}

\section{Article history:}

Received 11 October 2013

Received in revised form 2 September 2014

Accepted 11 September 2014

Available online 4 October 2014

Handling Editor: H. Fiedler

\section{Keywords:}

Polybrominated diphenyl ethers

Accumulation

Ducks

Time

Exposure levels

\begin{abstract}
A B S T R A C T
To reveal what degree bioaccumulation of polybrominated diphenyl ethers (PBDEs) depends on exposure time and other factors, we conducted a semi-field experiment for a year (June 2008-June 2009) in a village in an e-waste recycling site in Taizhou, China. Approximately one hundred of juvenile ducks (Anas domestica Linnaeus) were entrusted to a villager. The ducks lived and forged in a PBDE-polluted pond from the late March to the end of November. Fish and mudsnails that were heavily polluted by PBDEs were main food. In cold days (from December to the middle March), the ducks lived in the villager' house, and mainly fed on paddy, which contained lower concentrations of PBDEs than fish and mudsnails. The female ducks were sampled for PBDE analysis every three months. We found that the $\sum$ PBDE concentrations in duck liver, muscle, lung and brain fluctuated greatly with the changes of exposure levels that were determined by the environment and diets, but the $\sum$ PBDE concentrations in fat tissue increased successively with time. Congener analysis demonstrated that the successive increase in the $\sum$ PBDE concentrations with time in fat tissue was due to the successive increase in BDE-209, -183 and -153 concentrations, with large fluctuations of low brominated congeners. The results show that PBDE concentrations in liver, muscle, lung and brain tissues heavily depends on exposure levels rather than exposure time. In fat tissue, by contrast, PBDE concentrations (mainly high brominated congeners) slightly depends on exposure levels but heavily depend on time relative to other tissues, implying that high brominated congeners seem to have longer half-lives than low brominated congeners in fat tissue.
\end{abstract}

(c) 2014 Elsevier Ltd. All rights reserved.

\section{Introduction}

Polybrominated diphenyl ethers (PBDEs) are a class of widely used flame retardants in various products, including in textiles, polyurethane foams, thermoplastics and electronic products. Due to high levels of production and application, PBDEs have become ubiquitous environmental pollutants in the environment (Rahman et al., 2001; De Wit, 2002). PBDEs are also found in animals and human tissues because of their hydrophobicity and bioaccumula-

\footnotetext{
* Corresponding author. Tel.: +86106291 9177; fax: +86 1062923563.

E-mail address: qinzhanfen@rcees.ac.cn (Z.-F. Qin).
}

tion (McDonald, 2002; Darnerud, 2008). Animal studies have shown that PBDEs have a wide spectrum of toxicological effects, including thyroid disruption, developmental neurotoxicity, reproduction, immunotoxicity, etc. (Damerud, 2003). There are increasing epidemiological evidences that PBDEs might be associated with some parameters on human health (Chen et al., 2011; Chevrier et al., 2011; Bradman et al., 2012; Eskenazi et al., 2013). Due to bioaccumulation and potential toxicity, thus, PBDEs have aroused great concern. Deca-BDE products have still been produced and used widely, although commercial tetra- and octa-BDEs were added to Annex A of the Stockholm Convention PBDEs in 2009 (Alaee et al., 2003; Covaci et al., 2011). 
Numerous studies have demonstrated that the concentrations of some persistent organic pollutants (POPs), such as polychlorinated biphenyl (PCB), DDT, DDE, increase generally with exposure time or age in biotic tissues (Ronald et al., 1984; Johnson-Restrepo et al., 2005; Munoz-De-Toro et al., 2006; Mcgraw and Waller, 2009; Weijs et al., 2009; Goutner et al., 2011). However, a few of studies have demonstrated that PBDE bioaccumulation seems to increase with age in some biotic tissues (Riget et al., 2006; Kim et al., 2012), whereas some biomonitoring data show no association between PBDEs concentrations and time/age in biotic samples, such as fish (Zhang et al., 2010; Vigano et al., 2011), mammals (Rayne et al., 2004; Muir et al., 2006; Weijs et al., 2009), and humans (Covaci et al., 2008; Harrad and Porter, 2007; Kunisue et al., 2007). Overall, what degree PBDE bioaccumulation depends on exposure time and other factors has been unclear.

Taizhou in Zhejiang Province is one of the largest electric waste (e-waste) recycling areas in China. Recycling of e-waste using primitive methods has resulted in heavy PBDE pollution in the environment, although the primitive e-waste recycling has been controlled. In our previous studies, high concentrations of PBDEs were found in soils, sediments, animal tissues and human samples from some e-waste recycling sites in Taizhou (Liang et al., 2008; Yang et al., 2008; Zhao et al., 2009; Liu et al., 2011). To study what degree PBDE bioaccumulation depends on exposure time and other factors, in this study, we conducted a semi-field experiment in an e-waste recycling site in Taizhou to investigate changes in PBDE concentrations in ducks within a year and discuss crucial factors for PBDE accumulation.

\section{Materials and methods}

\subsection{Chemicals}

BDE-71 and ${ }^{13} \mathrm{C}$-labled BDE-209 as surrogate standards, and a standard solution of PBDE congeners (EO-5278, BDE-28, -47, -99, $-100,-153,-154,-183,-209$.) were obtained from Cambridge Isotope Laboratories (USA). Methylene dichloride, n-Hexane, and nonane were of pesticide grade and purchased from Tedia (USA).

\subsection{Semi-field experiment on ducks}

During June 2008-June 2009, we conducted a semi-field experiment in a village in Taizhou, where a mass of e-wastes from abroad as well as home were disassembled and shattered into powder to obtain the usable materials, and discarded e-waste powder was stacked around this village. We purchased about one hundred of one-month-old ducks (Anas domestica Linnaeus) from a farm (no factory and e-waste recycling site in the surrounding) in Zhejiang, and entrusted a villager in this village with them. The villager' house was approximately $500 \mathrm{~m}$ away from the foot of a hill, where a mass of e-waste powder was stacked. There was a pond in the front of the villager' house. When raining, rain water from the foot of the hill flew into the pond. From the late March to the end of November, the ducks forged in the pond at daytime, and went back to their nest in the villager' house at night. In the pond, there were a lot of mudsnails and fish, which were good food for the ducks. In cold days, from December to the early March, these ducks lived in the villager' house, and they mainly fed on paddy. The semi-field experiment began on June 15, when we sampled 3 ducks to examine background PBDE levels in the ducks. On September 15 (the 3rd month), December 15 (the 6th month), March 15 (the 9th month) and the next June 15 (the 12th month), the ducks were sampled for PBDE analysis. Because most ducks died in the first month after the beginning of the experiment, we only sampled 3 female ducks each time. The ducks sampled in the 3rd month never laid eggs, whereas the ducks sampled in the 6th, 9th and 12th month laid eggs. As live ducks were transferred to the laboratory, they were anesthetized and weighed. Liver, lung, muscle, fat and brain tissues were collected. All samples were cleaned with deionized water, weighed and wrapped in aluminum foil twice, and sealed in plastic bags to minimize the possibility of contamination. Then, samples were stored at $-20^{\circ} \mathrm{C}$ in darkness until analysis.

At the beginning of the semi-field experiment, we collected the water, sediment, mudsnail and fish samples from this pond. The water samples $(40 \mathrm{~L})$ were filtered through glass fiber filters ( $0.8 \mu \mathrm{m}$ pore size) and the filtrate was passed through a XAD- 2 resins column (Supelco, Bellfonte, USA), which was pre-extracted with methanol, dichloromethane and hexane, to enrich PBDEs on-site. Then, the XAD- 2 resins column and sediment samples were stored in a cool box and transported to laboratory. The eluent was concentrated to about $2 \mathrm{~mL}$ in a rotary evaporator. Then the sample solution was transferred to a vial and reduced to a volume of $20 \mu \mathrm{L}$ under a gentle stream of $\mathrm{N}_{2}$. The sediment samples were stored at $4{ }^{\circ} \mathrm{C}$ in darkness until analysis. Sediment samples were taken from approximately the top $2 \mathrm{~cm}$ of the sediment and each was constituted by five subsamples. The sediment samples $(n=3)$ were weighed and wrapped in aluminum foil and sealed in plastic bags on-site. All fish and mudsnails sampled in the pond were transferred to the laboratory for PBDE analysis. In the laboratory, the fish was rinsed with deionized water for three times, weighed and stored at $-20{ }^{\circ} \mathrm{C}$ in darkness until analysis. After washed with deionized water, live mudsnails were placed in cool fresh water to expel the sediment and sand inside their body. The fresh water was replaced five times within $24 \mathrm{~h}$. After the shells of mudsnails were removed, the samples were washed again, weighed and stored at $-20^{\circ} \mathrm{C}$ in the dark until analysis. Meanwhile, the rice as duck diet was also collected for PBDE analysis.

\subsection{Extraction}

The tissue samples were freeze-dried and homogenized with anhydrous sodium sulfate, then spiked with BDE-71, and ${ }^{13} \mathrm{C}$-labled BDE-209. The samples were subsequently extracted by ultrasonic extraction for twice with $30 \mathrm{~mL}$ of n-hexane/dichloromethane $(1: 1, \mathrm{vol} / \mathrm{vol})$. Then the combined extracts were evaporated to dryness for gravimetric determination of extracted lipid content. The concentrated extract was cleaned by passing through a $15 \mathrm{~mm}$ i.d. column, which was packed, from the bottom to top, with $1 \mathrm{~g}$ activated silica gel, $3 \mathrm{~g}$ alkaline silica gel (33\% sodium hydroxide, w/w), $1 \mathrm{~g}$ activated silica gel, $4 \mathrm{~g}$ acid silica gel $(44 \%$ concentrated sulfuric acid, w/w), $4 \mathrm{~g}$ acid silica gel (22\% concentrated sulfuric acid, w/w), $1 \mathrm{~g}$ activated silica gel, and $2 \mathrm{~cm}$ anhydrous sodium sulfate. The extract was eluted with $100 \mathrm{~mL}$ of hexane, concentrated to $2 \mathrm{~mL}$ using a rotary evaporator, transferred, and finally concentrated to approximately $0.1 \mathrm{~mL}$ under a gentle nitrogen stream. The final extract was transferred to GC vials. Throughout the extraction, cleanup and analysis procedures, the analyte was protected from light by wrapping the containers with aluminum foil or by using amber glassware.

\subsection{PBDE analysis}

All sample extracts were analyzed by Agilent 6890 series gas chromatograph coupled with Agilent 5973 mass spectrometer (Agilent Technologies, Palo Alto, CA, USA) using negative chemical ionization ( $\mathrm{NCI}$ ) source in the selected ion monitoring (SIM) mode. The gas chromatography column was DB-5 MS fused silica capillaries ( $15 \mathrm{~m}, 250-\mu \mathrm{m}$ inner diameter, $0.25 \mu \mathrm{m}$ film thickness). The injector and interface temperature were 265 and $300{ }^{\circ} \mathrm{C}$, respectively. The samples were injected in the pulsed splitless mode. 
Methane was used as the chemical ionization moderating gas and helium as the carrier gas at a flow rate of $1.0 \mathrm{~mL} \mathrm{~min}^{-1}$. The GC oven temperature program was carried out as follows: start at $100{ }^{\circ} \mathrm{C}$, held for $1 \mathrm{~min}$, increased to $200{ }^{\circ} \mathrm{C}$ at $10^{\circ} \mathrm{C} \mathrm{min}^{-1}$, and then to $300{ }^{\circ} \mathrm{C}$ at $20^{\circ} \mathrm{C} \mathrm{min}^{-1}$, held for $20 \mathrm{~min}$. The ions of $\mathrm{m} / \mathrm{z} 79$ and 81 were monitored for BDE-28, $-47,-100,-99,-154,-153,-183$ and $\mathrm{m} / \mathrm{z} 486.7$ and 488.7 for BDE-209.

\subsection{Quality assurance/quality control}

To avoid potential sample contamination, cross contamination, and PBDE degradation, proper handling was adopted from sample collection to chemical analysis. One procedural blank was run for every batch of nine samples to check the potential contamination from analysis process. Instrumental quality control was done by regular injection of solvent blanks and standard solutions. Recoveries of surrogate standards BDE-71 and ${ }^{13} \mathrm{C}$-labled BDE-209 were on average $84 \pm 12 \%$ and $65 \pm 8 \%$, respectively. Analyte value of BDE-209 was corrected for the recovery of ${ }^{13} \mathrm{C}$-labled BDE-209, and the other congeners were corrected for the recovery of BDE-71. The limit of detection (LOD) was defined as the concentration of analyte in the sample producing a peak with the ratio of signal to noise of 3 (peak-to-peak). Non-detect or below LOD values were estimated as zero for the purpose of calculating totals and means. For the tissue samples, LODs ranged from 0.005 to $0.025 \mathrm{ng} \mathrm{g}^{-1}$ wet weight (wet wt) for tri- to hepta- BDE, and $0.03 \mathrm{ng} \mathrm{g}^{-1}$ wet weight for deca-BDE.

\subsection{Data analysis}

All the statistical analysis was performed using SPSS software version 16.0 (SPSS Inc., Chicago, USA). The difference in body weight was tested by one-way analysis of variance. The concentrations of $\sum$ PBDEs and each congener in each tissue for adjacent sampling times were analyzed by $t$-test. $P<0.05$ was regarded as statistically significant.

\section{Results and discussion}

\subsection{PBDE levels and congener profiles in the surroundings and diets for ducks}

Table 1 shows the concentrations of PBDEs in water (dissolved phase and particulate phase), sediment, fish and mudsnails in the study pond as well as paddy samples as duck diets from the ewaste recycling site. The PBDE concentrations in sediment (8551.04 $\mathrm{ng} \mathrm{g}^{-1}$ dry weight) and water (42.00 $\mathrm{ng} \mathrm{L}^{-1}$ ) were much higher than the general levels reported in previous studies (Hale et al., 2003; Law et al., 2003; Yogui and Sericano, 2009). High values of PBDEs detected in water and sediment indicated that e-waste recycling resulted in PBDE pollution in this study area.
The average concentrations of PBDEs in fish and mudsnails in the study pond were $158.40 \mathrm{ng} \mathrm{g}^{-1}$ wet wt and $3.40 \mathrm{ng} \mathrm{g}^{-1}$ wet wt, respectively, while the average PBDE concentration in paddy was $4.14 \mathrm{ng} \mathrm{g}^{-1}$ dry weight. The ducks in the semi-wild experiment would absorb much PBDEs via the uptake of fish and mudsnails and direct contact with the water and sediment in the study pond relative to via the uptake of paddy, although we could not measure daily intake of PBDEs by the ducks.

There was a large difference in congener profiles of PBDEs between environmental samples and biotic samples from the study pond (Fig. 1). BDE-209 was the dominant congener in sediment and water, in particular, BDE-209 contributed $73.31 \%$ of the total PBDEs in water. However, low brominated congeners (BDE-28, $-47,-99)$ were main congeners, whereas high brominated congeners (BDE-209 and BDE-183) were less in fish and mudsnails. The observation is consistent with previous reports that aquatic organisms accumulated much low brominated PBDE congeners and less high brominated congeners from the environment with more high brominated congeners and less low brominated congeners was consistent with previous reports (Sellstrom et al., 1998; Boon et al., 2002; Guo et al., 2008). In paddy samples as duck diets, BDE-209 accounted for approximately $80 \%$ of the total PBDEs. Thus, the ducks can absorb much high brominated PBDE congeners by direct contact with the sediment and water in the pond. On the contrary, the ducks can absorb much low brominated congeners by the intake of fish and mudsnails. In addition, the ducks can also absorb much BDE-209 by local paddy.

\subsection{Growth of ducks and changes in $\sum P B D E$ concentrations in various tissues within a year}

The ducks rapidly grew up before the first sampling. No significant difference in body weight was found among ducks collected for four sampling times, despite body weight of the ducks collected for the third time was slightly low (Table 2). The ducks sampled in the 3rd month never laid eggs, but there were some developing eggs in the abdomens. The ducks sampled in the 6th, 9th and 12th month laid eggs. Fig. 2 and Table 2 shows the $\sum$ PBDE concentrations (ng $\mathrm{g}^{-1}$ lipid weight) in fat, liver, lung, muscle, and brain tissues of the ducks. Statistical analysis ( $t$-test) of the data for adjacent sampling times revealed a rough fluctuation of $\sum$ PBDE concentrations with time. Before the beginning of the semi-field experiment, the ducks had low body burden of PBDEs. After 3 months, the $\sum$ PBDE concentrations in ducks increased dramatically. The $\sum$ PBDE concentrations in liver, muscle, lung and brain tissues fluctuated within a year. In detail, the $\sum$ PBDE concentrations increased in the 6th month relative to the 3rd month, decreased in the 9th month relative to the 6 th month, then, increased again during the last 3 months of the semi-field experiment.

It is generally believed that the growth possibly results in decreases in pollutant concentrations in the body, so called biodilution (Hammer et al., 1993; Blais et al., 2003). Considering the lack

Table 1

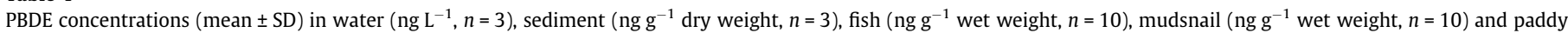
(ng g ${ }^{-1}$ dry weight, $n=3$ ) samples from an e-waste recycling site.

\begin{tabular}{|c|c|c|c|c|c|}
\hline Compound & Water & Sediment & Fish & Mudsnail & Paddy \\
\hline BDE-28 & $0.92 \pm 0.08$ & $263.90 \pm 34.21$ & $30.83 \pm 2.46$ & $0.40 \pm 0.05$ & $0.03 \pm 0.00$ \\
\hline BDE-4 & $4.89 \pm 0.34$ & $1972.30 \pm 212.37$ & $100.82 \pm 13.48$ & $1.39 \pm 0.12$ & $0.20 \pm 0.01$ \\
\hline BDE-99 & $3.80 \pm 0.27$ & $1805.90 \pm 193.38$ & $18.86 \pm 2.02$ & $0.93 \pm 0.16$ & $0.20 \pm 0.01$ \\
\hline BDE-100 & $0.16 \pm 0.01$ & $132.80 \pm 15.26$ & $1.86 \pm 0.20$ & $0.09 \pm 0.01$ & $0.12 \pm 0.01$ \\
\hline BDE-153 & $0.81 \pm 0.04$ & $562.00 \pm 67.34$ & $4.03 \pm 0.47$ & $0.20 \pm 0.03$ & $0.08 \pm 0.01$ \\
\hline BDE-154 & $0.28 \pm 0.01$ & $189.90 \pm 19.47$ & $1.26 \pm 0.12$ & $0.09 \pm 0.01$ & $0.08 \pm 0.01$ \\
\hline BDE-183 & $0.35 \pm 0.02$ & $621.20 \pm 78.17$ & $0.72 \pm 0.08$ & $0.10 \pm 0.01$ & $0.04 \pm 0.00$ \\
\hline BDE-209 & $30.79 \pm 2.26$ & $3003.00 \pm 483.96$ & $0.02 \pm 0.01$ & $0.21 \pm 0.03$ & $3.39 \pm 0.21$ \\
\hline$\sum$ PBDEs & $42.00 \pm 3.42$ & $8551.04 \pm 921.14$ & $158.40 \pm 16.69$ & $3.40 \pm 0.49$ & $4.14 \pm 0.24$ \\
\hline
\end{tabular}




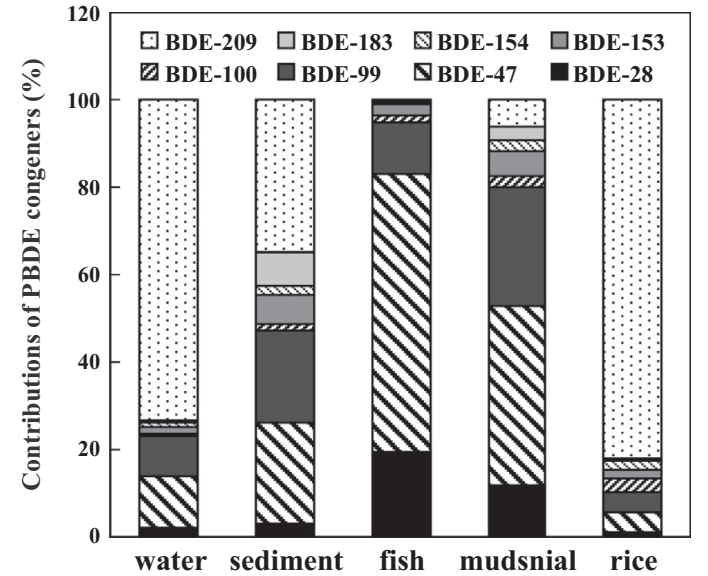

Fig. 1. Congener profiles of polybrominated diphenyl ethers (PBDEs) in water $(n=3)$, sediment $(n=3)$, fish $(n=10)$, mudsnails $(n=10)$ and rice $(n=3)$ samples from an e-waste recycling area.

of significant difference in body weight among the ducks collected at four sampling times, biodilution may not be explained as a

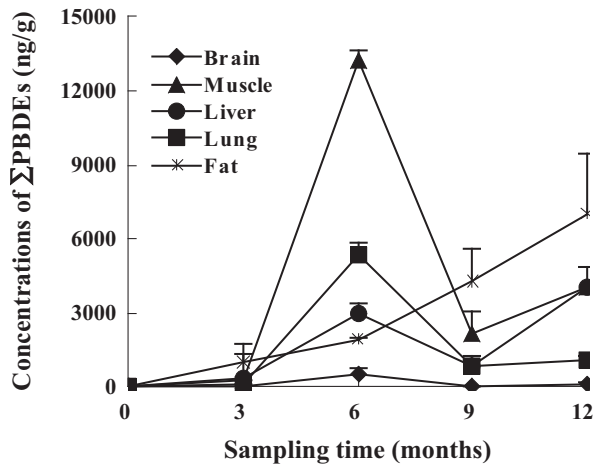

Fig. 2. Changes in the mean concentrations of $\sum$ PBDE (ng g ${ }^{-1}$ lipid weigh) in various tissues of the ducks $(n=3)$ within a year in the semi-field experiment.

contributing factor for the fluctuation of PBDE concentrations in duck tissues with time. In addition, previous studies suggested that laying eggs could cause a decrease in body burden of pollutants in birds (Van den Steen et al., 2009; Akearok et al., 2010). In our study, the ducks sampled in the 3rd month cannot lay eggs because

Table 2

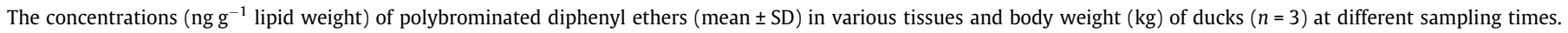

\begin{tabular}{|c|c|c|c|c|c|c|c|c|}
\hline Sampling time & Compound & Muscle & Liver & Lung & Brain & Fat & Body weight & Laying status \\
\hline \multirow[t]{9}{*}{0 month } & BDE-28 & $<$ LOD & $<$ LOD & $<$ LOD & $<\mathrm{LOD}$ & $<$ LOD & & \\
\hline & BDE-47 & $<$ LOD & $0.03 \pm 0.02$ & $<$ LOD & $<$ LOD & $0.15 \pm 0.12$ & & \\
\hline & BDE-99 & $<$ LOD & $0.02 \pm 0.02$ & $<$ LOD & $<\mathrm{LOD}$ & $0.42 \pm 0.36$ & & \\
\hline & BDE-100 & $<$ LOD & $<\mathrm{LOD}$ & $<$ LOD & $<\mathrm{LOD}$ & $0.05 \pm 0.07$ & & \\
\hline & BDE-153 & $<$ LOD & $0.08 \pm 0.11$ & $<$ LOD & $<\mathrm{LOD}$ & $0.52 \pm 0.56$ & $1.21 \pm 0.05$ & No \\
\hline & BDE-154 & $<$ LOD & $<$ LOD & $<$ LOD & $<\mathrm{LOD}$ & $0.05 \pm 0.07$ & & \\
\hline & BDE-183 & $<$ LOD & $0.01 \pm 0.005$ & $0.02 \pm 0.02$ & $<\mathrm{LOD}$ & $0.81 \pm 0.73$ & & \\
\hline & BDE-209 & $0.31 \pm 0.17$ & $0.63 \pm 0.17$ & $0.51 \pm 0.02$ & $<\mathrm{LOD}$ & $1.28 \pm 0.63$ & & \\
\hline & $\sum$ PBDEs & $0.31 \pm 0.17$ & $0.71 \pm 0.35$ & $0.53 \pm 0.05$ & $<$ LOD & $3.27 \pm 2.49$ & & \\
\hline \multirow[t]{9}{*}{ the 3rd month } & BDE-28 & $0.26 \pm 0.06$ & $0.06 \pm 0.02$ & $0.14 \pm 0.04$ & $0.06 \pm 0.02$ & $0.34 \pm 0.00$ & & \\
\hline & BDE-47 & $0.50 \pm 0.38$ & $14.5 \pm 1.56$ & $11.7 \pm 3.39$ & $2.97 \pm 0.85$ & $53.9 \pm 0.65$ & & \\
\hline & BDE-99 & $3.16 \pm 1.25$ & $4.22 \pm 1.51$ & $14.5 \pm 4.05$ & $4.90 \pm 3.24$ & $121.1 \pm 53.3$ & & \\
\hline & BDE-100 & $2.80 \pm 2.58$ & $0.03 \pm 0.03$ & $1.98 \pm 0.25$ & $0.96 \pm 0.80$ & $19.30 \pm 10.3$ & & \\
\hline & BDE-153 & $1.14 \pm 0.55$ & $3.92 \pm 3.48$ & $10.4 \pm 3.66$ & $8.53 \pm 8.69$ & $160.4 \pm 68.6$ & $1.32 \pm 0.06$ & No \\
\hline & BDE-154 & $2.48 \pm 2.47$ & $0.89 \pm 0.56$ & $1.52 \pm 0.01$ & $0.70 \pm 0.58$ & $18.18 \pm 10.8$ & & \\
\hline & BDE-183 & $0.76 \pm 0.59$ & $3.37 \pm 1.02$ & $24.8 \pm 18.82$ & $18.1 \pm 15.2$ & $330 \pm 105.9$ & & \\
\hline & BDE-209 & $247.0 \pm 15.29$ & $349.5 \pm 61.19$ & $91.57 \pm 16.33$ & $12.66 \pm 6.64$ & $323.6 \pm 82.7$ & & \\
\hline & $\sum$ PBDEs & $258.1 \pm 11.03$ & $376.6 \pm 66.35$ & $156.55 \pm 1.55$ & $42.24 \pm 39.22$ & $1027 \pm 330.9$ & & \\
\hline \multirow[t]{9}{*}{ the 6th month } & BDE-28 & $16.6 \pm 0.51$ & $3.29 \pm 1.15$ & $5.23 \pm 4.18$ & $1.05 \pm 0.38$ & $14.12 \pm 2.42$ & & \\
\hline & BDE-47 & $1549 \pm 40.3$ & $583.3 \pm 167$ & $666 \pm 409$ & $110 \pm 84.72$ & $530.5 \pm 23.6$ & & \\
\hline & BDE-99 & $2033 \pm 161.7$ & $422.6 \pm 132$ & $877.9 \pm 570$ & $176.9 \pm 93$ & $556.9 \pm 46.02$ & & \\
\hline & BDE-100 & $155.7 \pm 58.3$ & $4.50 \pm 2.77$ & $60.4 \pm 40.8$ & $10.3 \pm 5.12$ & $142.1 \pm 58.49$ & & \\
\hline & BDE-153 & $918.5 \pm 129.7$ & $114.2 \pm 102$ & $267.8 \pm 140$ & $100.9 \pm 67.8$ & $195.3 \pm 26.77$ & $1.45 \pm 0.07$ & Yes \\
\hline & BDE-154 & $190.9 \pm 95.60$ & $33.64 \pm 31.2$ & $52.90 \pm 36.1$ & $12.65 \pm 9.49$ & $75.88 \pm 27.30$ & & \\
\hline & BDE-183 & $1411 \pm 467.2$ & $100.1 \pm 83.9$ & $328.5 \pm 61.6$ & $68.23 \pm 32.8$ & $177.2 \pm 13.38$ & & \\
\hline & BDE-209 & $6969 \pm 366.2$ & $2753 \pm 325.9$ & $3423 \pm 946.7$ & $32.43 \pm 17.50$ & $263.3 \pm 109.1$ & & \\
\hline & $\sum$ PBDEs & $13245 \pm 384.1$ & $3014 \pm 1412$ & $5397 \pm 476.8$ & $512.5 \pm 279.0$ & $1955 \pm 62.16$ & & \\
\hline \multirow[t]{9}{*}{ the 9th month } & BDE-28 & $0.56 \pm 0.09$ & $0.16 \pm 0.09$ & $0.38 \pm 0.09$ & $0.07 \pm 0.01$ & $1.04 \pm 0.79$ & & \\
\hline & BDE-47 & $137 \pm 9.43$ & $94.3 \pm 21.1$ & $48.6 \pm 17.8$ & $12.14 \pm 3.9$ & $203 \pm 105$ & & \\
\hline & BDE-99 & $215 \pm 32.5$ & $72.2 \pm 72.5$ & $77.6 \pm 29.2$ & $18.97 \pm 5.5$ & $332.4 \pm 137.7$ & & \\
\hline & BDE-100 & $16.8 \pm 1.60$ & $5.43 \pm 7.16$ & $6.90 \pm 2.30$ & $1.63 \pm 0.42$ & $114.6 \pm 100.6$ & & \\
\hline & BDE-153 & $112 \pm 43.5$ & $97.4 \pm 91.3$ & $56.7 \pm 19.4$ & $13.9 \pm 3.31$ & $274.0 \pm 50.71$ & $1.22 \pm 0.09$ & Yes \\
\hline & BDE-154 & $33.3 \pm 19.6$ & $4.26 \pm 5.88$ & $12.4 \pm 4.09$ & $2.32 \pm 0.79$ & $43.41 \pm 27.35$ & & \\
\hline & BDE-183 & $400 \pm 234.8$ & $28.7 \pm 28.4$ & $160 \pm 98.73$ & $11.11 \pm 6.53$ & $598.7 \pm 107.4$ & & \\
\hline & BDE-209 & $1261 \pm 645.2$ & $552.1 \pm 314.8$ & $466.6 \pm 204.7$ & $1.29 \pm 0.89$ & $2722 \pm 1026$ & & \\
\hline & $\sum$ PBDEs & $2178 \pm 867.1$ & $854.5 \pm 375.1$ & $829.2 \pm 245.5$ & $61.45 \pm 13.18$ & $4290 \pm 1332$ & & \\
\hline \multirow[t]{9}{*}{ the 12 th month } & BDE-28 & $0.05 \pm 0.02$ & $0.15 \pm 0.03$ & $0.20 \pm 0.06$ & $<$ LOD & $0.11 \pm 0.13$ & & \\
\hline & BDE-47 & $51.5 \pm 31.1$ & $193.8 \pm 78$ & $39.9 \pm 26.6$ & $14.5 \pm 4.37$ & $176.5 \pm 104$ & & \\
\hline & BDE-99 & $22.6 \pm 2.72$ & $46.7 \pm 7.55$ & $12.32 \pm 2.5$ & $1.44 \pm 0.47$ & $54.92 \pm 18.3$ & & \\
\hline & BDE-100 & $193 \pm 100.8$ & $232 \pm 117.8$ & $104.7 \pm 62.1$ & $42.1 \pm 15.2$ & $504.4 \pm 218.2$ & & \\
\hline & BDE-153 & $274.9 \pm 75.1$ & $639.6 \pm 96.7$ & $112.1 \pm 25.5$ & $31.1 \pm 5.14$ & $572.3 \pm 116.8$ & $1.33 \pm 0.12$ & Yes \\
\hline & BDE-154 & $35.30 \pm 4.00$ & $139.6 \pm 8.68$ & $18.30 \pm 0.68$ & $5.89 \pm 0.21$ & $177.6 \pm 58.37$ & & \\
\hline & BDE-183 & $673.5 \pm 151.4$ & $1339 \pm 83.45$ & $284.2 \pm 66.2$ & $32.34 \pm 8.72$ & $1196 \pm 694.6$ & & \\
\hline & BDE-209 & $2866 \pm 689.2$ & $1477.4 \pm 231.7$ & $548.8 \pm 123.5$ & $1.43 \pm 0.20$ & $4338.1 \pm 1944.8$ & & \\
\hline & $\sum$ PBDEs & $4090 \pm 784.9$ & $4069 . \pm 371.1$ & $1120 \pm 124.8$ & $128.8 \pm 32.9$ & $7020.4 \pm 2406.5$ & & \\
\hline
\end{tabular}




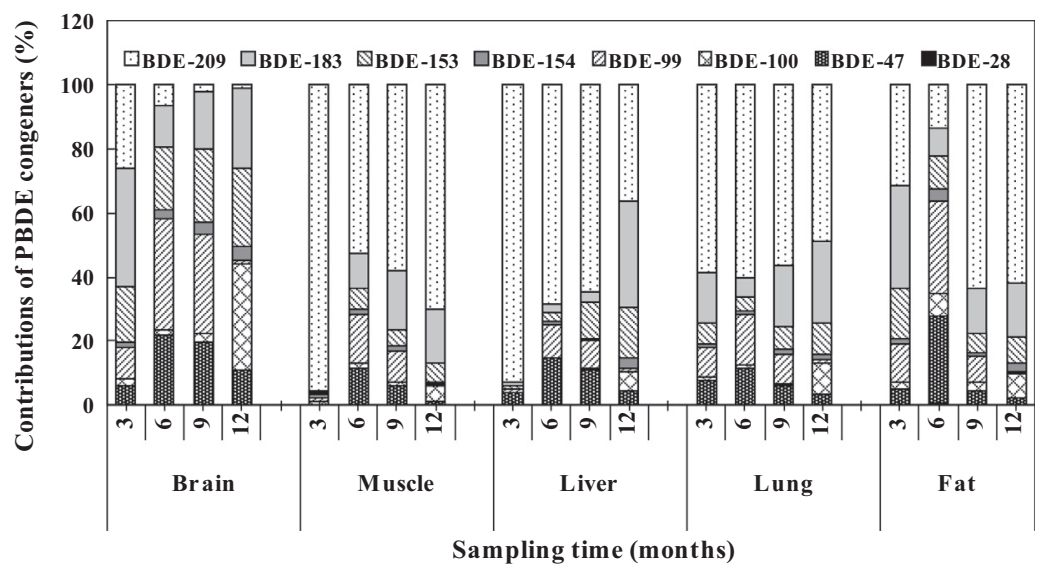

Fig. 3. Congener profiles of polybrominated diphenyl ethers in various tissues of the ducks $(n=3)$ within a year in the semi-field experiment.

of young age (four-month-old), whereas the ducks sampled in the 6 th month were laying eggs. However, PBDE concentrations in the samples for the 6th month were obviously higher than the corresponding concentrations in the samples for the 3th month. Thus, laying eggs may not be a contributing factor for the fluctuation of PBDE concentrations in duck tissues with time.

Except for the growth and laying eggs, it can be explained that the fluctuation in the $\sum$ PBDE concentrations in liver, muscle, lung and brain tissues may result from the changes of exposure levels due to season change. In the first 3 months (from June 15 to September 15) of the semi-field experiment, the weather was hot summer and the ducks lived in the pond at daytime, and went back to their nest in the villager' house at night. In this period, the ducks fed on PBDE-contaminated mudsnails and fish in the pond, resulting in PBDE accumulation in the duck tissues. During most of the following 3 months from September 16 to December 15, the ducks still forged in this pond because the weather was still warm in most of the period (before the end of November). Therefore, the PBDE concentrations in the duck tissues sampled on December 15 were higher than those in the duck tissues sampled on September 15, exhibiting that the PBDE concentrations increased continuously. The weather became cold in the beginning of December, and the ducks were raised in the villager' house until the middle March in the next year. In this period, the ducks fed mainly on the paddy, in which the PBDE level was lower than in mudsnails and fish. Moreover, the ducks cannot absorb PBDEs by direct contact with PBDE-contaminated sediment and water. Therefore, the $\sum$ PBDE concentrations in the duck tissues sampled on March 15 declined relative to the $\sum$ PBDE levels in the tissues collected at the second time. Since the middle March, the weather got warm and the duck returned the pond, in which they were exposed again to high PBDE levels via mudsnails and fish as their diets, with direct contact with PBDE-contaminated sediment and water. The fluctuation in the $\sum$ PBDE concentrations with the changes in the exposure levels (the environment and diets) demonstrate that PBDEs are easily eliminated/metabolized in liver, muscle, lung and brain tissues of ducks. When the exposure level decreases, the PBDE concentrations in these tissues will decline quickly. In consistence with our results, rapid elimination rates and short half-lives (ranging several days to 2-3 months) of PBDE in animal tissues have been shown in previous studies (Tomy et al., 2004; Staskal et al., 2005; Liu et al., 2011). Thus, it is concluded that PBDE concentrations in liver, muscle, lung and brain tissues depend mainly on exposure level rather than on exposure time. When the exposure level decreases, PBDE concentrations in these tissues no longer increase, even, decrease with time. Our study could explain the lack of association between PBDE levels in animal and human tissues and ages in previous reports (Covaci et al., 2008; Harrad and Porter, 2007; Kunisue et al., 2007).

In contrast to liver, muscle, lung and brain tissues, the $\sum$ PBDE concentrations in fat tissue increased successively with time in spite of the changes in the exposure levels to PBDEs. The findings imply that PBDEs are more accumulative relative to metabolism and excretion in fat tissue than in other tissues, resulting in a successive increase in PBDE concentrations in fat tissue. In addition, the transfer of PBDEs from other tissues to fat tissue might be a cause of a successive increase in PBDE concentrations in fat tissue with time, even if the exposure levels fluctuated at a great range. In consistence with our study, Staskal et al. (2005) also reported that following treatment with BDE-47 female mice, more BDE-47 was deposited in fat tissue than in liver, lung, brain and muscular tissues, with longer half-lives in fat tissue than in other tissues. The difficulty of releasing hydrophobic chemicals from fat tissue may be a reasonable explaination for our observations. Similar to PBDEs, PCBs as another class of lipophilic chemicals have been also demonstrated to tend to be retained in fat tissues relative to in other tissues (Mühlebach and Bickel, 1981; Hu et al., 2010).

Considering the stability of PBDE concentrations in fat tissue relative to other tissues, our results demonstrate that adipose tissue is the best bioindicator of monitoring PBDE pollution. In fact, many studies examined PBDE concentrations in fat tissue to indicate PBDE pollution levels in biotic samples (Pulkrabová et al., 2009; Hurley et al., 2011; Roszko et al., 2013). However, most of these studies reported no association between PBDE concentrations and age/exposure time, suggesting that bioaccumulation of PBDE, in fat tissue still depends on exposure levels (Malarvannan et al., 2013; Verreault et al., 2009; Pulkrabová et al., 2009).

It is noteworthy that the brain exhibited the lowest PBDE burden among all tissues. This phenomenon was also observed in birds and rodents (Voorspoels et al., 2006; Zhang et al., 2011). It is suggested that the blood-brain barrier (BBB) could protect to some degree the brain from PBDE accumulation (Bachour et al., 1998; Voorspoels et al., 2006).

\subsection{Congener profiles and changes in the levels of PBDE congener within a year}

The congener profiles of PBDEs detected in various duck tissues are shown in Fig. 3. BDE-209 and BDE-183 contributed more than $50 \%$ of the total PBDEs in muscle, liver, and lung tissues. In fat tissues, BDE-209 and BDE-183 were also dominant congeners except for the samples collected at the third time whereas, in which BDE47 and BDE-99 were main congeners. In contrast to other tissues, high brominated congeners in the brain had less contribution to 
A

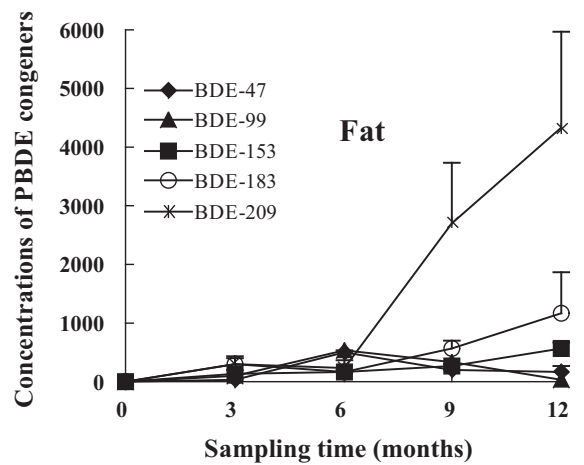

B

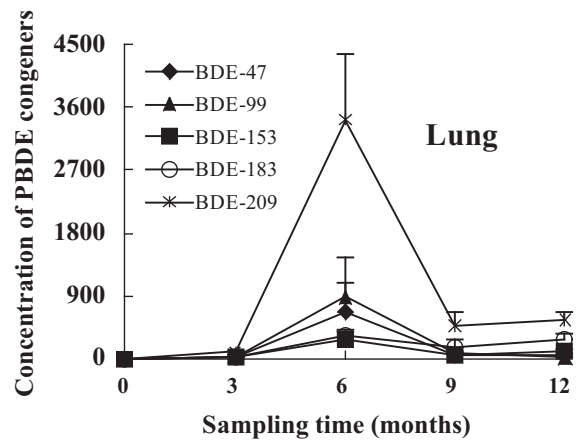

C

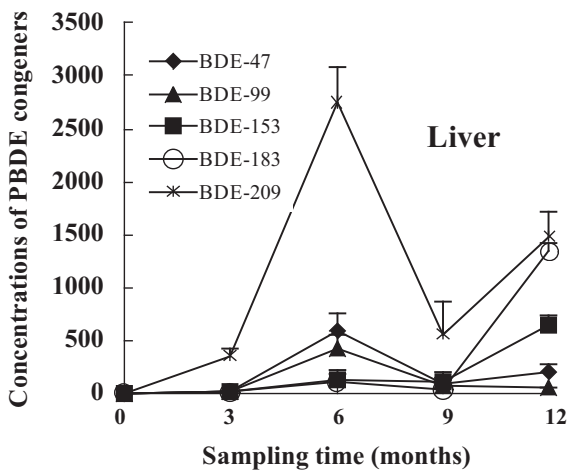

D

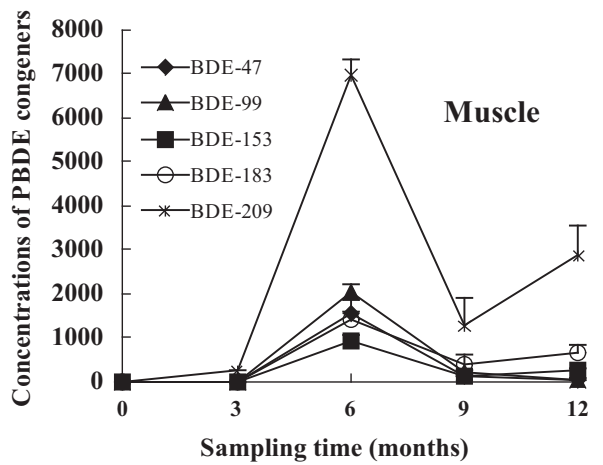

a

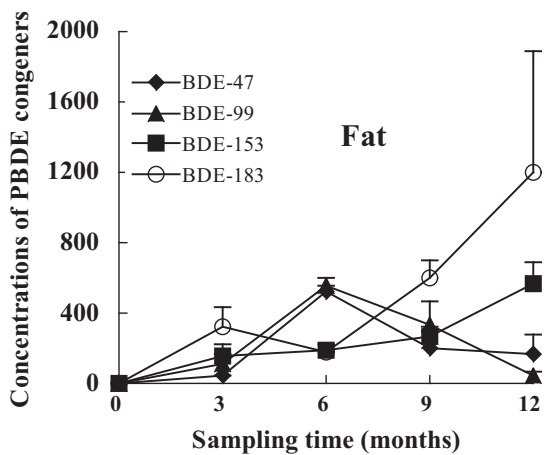

b

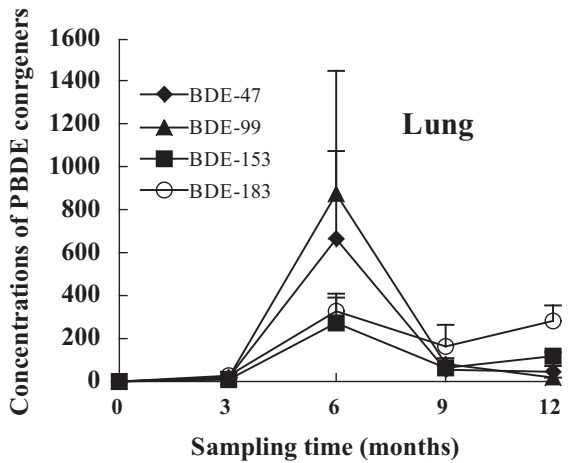

c

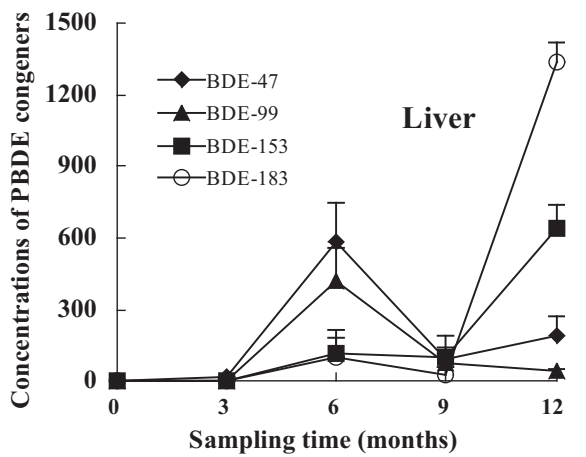

$\mathbf{E}$

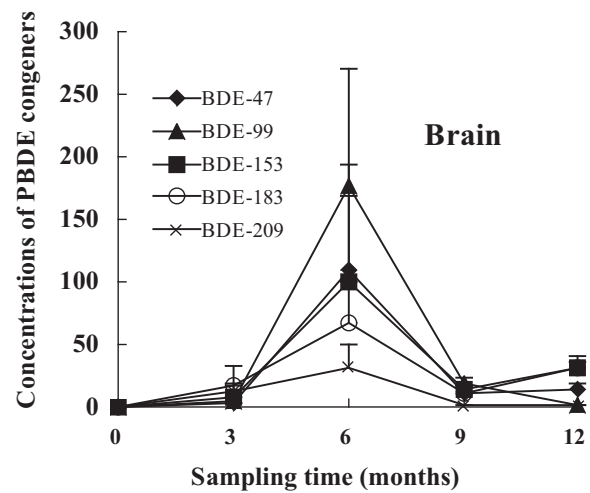

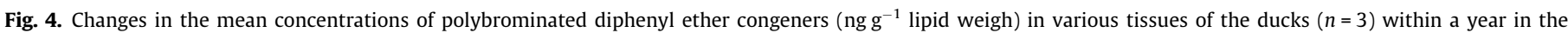
semi-field experiment. (A, B, C, D, E: for each PBDE congeners; a, b, c: for other PBDE congeners except BDE-209).

the total PBDE concentration relative to low brominated congeners. More low brominated congeners and less high brominated congeners in the brain relative to other tissues were reported in previous studies (Law et al., 2006; Luo et al., 2007). The phenomenon suggests that low brominated congeners might cross more easily the BBB to enter the brain than high brominated congeners.
The change trends in the concentrations of each PBDE congener in the liver, lung, muscle and brain accorded with the change trends in the total PBDE concentrations (Fig. 4). In detail, the concentrations of each PBDE congener increased in the 6th month relative to the 3 rd month, decreased in the 9 th month relative to the 6th month, then, increased again during the last 3 months of 
the semi-field experiment. In fat tissue, however, not at all PBDE congeners exhibited a similar change trend with the $\sum$ PBDE concentration trend. BDE-209, -183 , and -153 concentrations in fat tissue successively increased with time, which was consistent with the change trend of the $\sum$ PBDE concentration. In contrast to BDE-209, -183 and -153 , low brominated congeners in fat tissues had fluctuating concentrations, like in other tissues. In this way, the successive increase in the $\sum$ PBDE concentration with time was due to the successive increase in the concentrations of BDE-209, -183 and -153 in fat tissues. The data show that BDE$209,-183$ and -153 are more stable relative to low brominated congeners in duck fat tissue, whereas low brominated congeners are more easily eliminated/metabolized in duck fat tissue.

Several previous reports demonstrated an order of the half-life on BDE-153 > BDE-99 > BDE-47 in animal tissues (Tomy et al., 2004; Drouillard et al., 2007; Von Meyerinck et al., 1990; Liu et al., 2011), showing that the half-life of PBDE congener becomes longer with the increase of bromine atom numbers from tetra- to hexaBDEs. These studies could explain our findings that the concentrations of low brominated congeners had large fluctuations, whereas BDE-153 concentrations exhibited a successive increase in duck fat tissue along with the changes of background exposure level and time. However, it is interesting that the concentrations of BDE209 and BDE-183 increased successively in fat tissues in spite of a large fluctuation of exposure levels of these congeners. In general, BDE-209 is believed to has a short half-life in blood and whole body in animals or humans due to debromination (Thuresson et al., 2006; Huwe and Smith, 2007; Munschy et al., 2011). Huwe and Smith (2007) concluded that the whole body half-lives tended to decrease with the increase of bromine atom numbers from octa- to Deca-BDEs in rats. To our knowledge, little information is available concerning the half-lives of PBDE congeners in fat tissue. Only a study investigated toxicokinetics of BDE-47 in female mice, and showed that the half-live of BDE-47 in fat tissue was possibly longer than in the other tissues, such as liver, lung, brain, and muscle (Staskal et al., 2005) In this study, our findings that BDE-209, -183 and -153 concentrations did not decline in fat tissue but markedly declined in other tissues with the decrease in exposure levels suggest that these congeners have longer half-lives in fat tissue than in other tissues. In fat tissue, moreover, the successive increase in BDE-209, -183 and -153 concentrations and large fluctuations of low brominated congener concentrations along with the changes of the background exposure level possibly imply that high brominated congeners have longer half-lives than low brominated congeners in fat tissue. We explain that higher lipophilicity (high $\log$ Kow value) of high brominated congeners is possibly responsible for longer half-lives than low brominated congeners in fat tissue. Our opinion accords with the general assumption that the elimination rates of PBDEs decrease with the increase of log Kow and bromine atom number (Gustafsson et al., 1999; Liang et al., 2010).

In conclusion, our study show that PBDE bioaccumulation in liver, muscle, lung and brain tissues heavily depends on exposure levels rather than exposure time, with rapid changes in the PBDE levels with changes in exposure levels. However, PBDE bioaccumulation (mainly high brominated congeners) in fat tissue slightly depends on exposure levels relative to other tissues, resulting in an increase in the PBDE levels in fat tissue with time. The results imply that high brominated congeners seem to have longer halflives than low brominated congeners in fat tissue.

\section{Acknowledgements}

This work was supported by grants from Hi-Tech Research and Development Program of China (863 Plan) (2012AA06A302), the Strategic Priority Research Program of the Chinese Academy of
Sciences (XDB14040102), and National Natural Science Foundation of China - Chaina (21077125).

\section{References}

Akearok, J.A., Hebert, C.E., Braune, B.M., Mallory, M.L., 2010. Inter- and intraclutch variation in egg mercury levels in marine bird species from the Canadian Arctic. Sci. Total Environ. 15, 836-840.

Alaee, M., Arias, P., Sjöin, A., Bergman, A., 2003. An overview of commercially used brominated flame retardants, their applications, their use patterns in different countries/regions and possible modes of release. Environ. Int. 29, 683-689.

Bachour, G., Failing, K., Georgii, S., Elmadfa, I., Brunn, H., 1998. Species and organ dependence of PCB contamination in fish, foxes, roe deer, and humans. Arch. Environ. Contam. Toxical. 35, 666-673.

Blais, J.M., Wilhelm, F., Kidd, K.A., Muir, D.C.G., Donald, D.B., Schindler, D.W., 2003. Concentrations of organochlorine pesticides and PCBs in amphipods (Gammarus lacustris) along an elevation gradient in mountain lakes of western Canada. Environ. Toxicol. Chem. 22, 2605-2613.

Boon, J.P., Lewis, W.E., Tjoen-A-Choy, M.R., Allchin, C.R., Law, R.J., De Boer, J., Ten Hallers-Tjabbes, C.C., Zegers, B.N., 2002. Levels of polybrominated diphenyl ether (PBDE) flame retardants in animals representing different trophic levels of the North Sea food web. Environ. Sci. Technol. 36, 4025-4032.

Bradman, A., Castorina, R., Sjödin, A., Fenster, L., Jones, R.S., Harley, K.G., Chevrier, J., Holland, N.T., Eskenazi, B., 2012. Factors associated with serum polybrominated diphenyl ether (PBDE) levels among school-age children in the CHAMACOS cohort. Environ. Sci. Technol. 46, 7373-7381.

Chen, A., Chung, E., DeFranco, E.A., Pinney, S.M., Dietrich, K.N., 2011. Serum PBDEs and age at menarche in adolescent girls: analysis of the national health and nutrition examination survey 2003-2004. Environ. Res. 111, 831-837.

Chevrier, J., Harley, K.G., Bradman, A., Sjödin, A., Eskenazi, B., 2011. Prenatal exposure to polybrominated diphenyl ether flame retardants and neonatal thyroid-stimulating hormone levels in the CHAMACOS study. Am. J. Epidemiol. $174,1166-1174$.

Covaci, A., Voorspoels, S., Roosens, L., Jacobs, W., Blust, R., Neels, H., 2008. Polybrominated diphenyl ethers (PBDEs) and polychlorinated biphenyls (PCBs) in human liver and adipose tissue samples from Belgium. Chemosphere 73, 170-175.

Covaci, A., Harrad, S., Abdallah, M.A.E., Ali, N., Law, R.J., Herzke, D., De Wit, C.A., 2011. Novel brominated flame retardants: a review of their analysis, environmental fate and behaviour. Environ. Int. 37, 532-556.

Damerud, P.O., 2003. Toxic effects of brominated flame retardants in man and in wildlife. Environ. Int. 29, 841-853.

Darnerud, P.O., 2008. Brominated flame retardants as possible endocrine disrupters. Int. J. Androl. 31, 152-160.

De Wit, C.A., 2002. An overview of brominated flame retardants in the environment. Chemosphere 46, 583-624.

Drouillard, K.G., Fernie, K.J., Letcher, R.J., Shutt, L.J., Whitehead, M., Gebink, W., Bird, D.M., 2007. Bioaccumulation and biotransformation of 61 polychlorinated biphenyl and four polybrominated diphenyl ether congeners in juvenile American kestrels (Falco sparverius). Environ. Toxicol. Chem. 26, 313-324.

Eskenazi, B., Chevrier, J., Rauch, S.A., Kogut, K., Harley, K.G., Johnson, C., Trujillo, C., Sjödin, A., Bradman, A., 2013. In utero and childhood polybrominated diphenyl ether (PBDE) exposures and neurodevelopment in the CHAMACOS study. Environ. Health Perspect. 121, 257-262.

Goutner, V., Becker, P.H., Liordos, V., 2011. Organochlorines and mercury in livers of great cormorants (Phalacrocorax carbo sinensis) wintering in northeastern Mediterranean wetlands in relation to area, bird age, and gender. Sci. Total Environ. 409, 710-718.

Guo, L., Qiu, Y., Zhang, G., Zheng, G.J., Lam, P.K.S., Li, X., 2008. Levels and bioaccumulation of organochlorine pesticides (OCPs) and polybrominated diphenyl ethers (PBDEs) in fishes from the Pearl River estuary and Daya Bay, South China. Environ. Pollut. 152, 604-611.

Gustafsson, K., Bjork, M., Burreau, S., Gilek, M., 1999. Bioaccumulation kinetics of brominated flame retardants (polybrominateddiphenylethers) in blue mussels (Mytilus edulis). Environ. Toxicol. Chem. 18, 1218-1224.

Hale, R.C., Alaee, M., Manchester-Neesvig, J.B., Stapleton, H.M., Ikonomou, M.G., 2003. Polybrominated diphenyl ether flame retardants in the North American environment. Environ. Int. 29, 771-779.

Hammer, J., Larsson, P., Klavins, M., 1993. Accumulation of persistent pollutants in normal and dwarfed arctic char (Salvelinus alpinus sp. complex). Can. I. Fish. Aquat. Sci. 50, 2574-2580.

Harrad, S., Porter, L., 2007. Concentrations of polybrominated diphenyl ethers in blood serum from New Zealand. Chemosphere 66, 2019-2023.

Hu, X., Adamcakova-Dodd, A., Lehmler, H.J., Hu, D., Kania-Korwel, I., Hornbuckle, K.C., Thorne, P.S., 2010. Time course of congener uptake and elimination in rats after short-term inhalation exposure to an airborne polychlorinated biphenyl (PCB) mixture. Environ. Sci. Technol. 44 (17), 6893-6900.

Hurley, S., Reynolds, P., Goldberg, D., Nelson, D.O., Jeffrey, S.S., Petreas, M., 2011. Adipose levels of polybrominated diphenyl ethers and risk of breast cancer. Breast Cancer Res. Treat 129, 505-511.

Huwe, J.K., Smith, D.J., 2007. Accumulation, whole-body depletion, and debromination of decabromodiphenyl ether in male sprague-dawley rats following dietary exposure. Environ. Sci. Technol. 41, 2371-2377. 
Johnson-Restrepo, B., Kannan, K., Rapaport, D.P., Rodan, B.D., 2005. Polybrominated diphenyl ethers and polychlorinated biphenyls in human adipose tissue from New York. Environ. Sci. Technol. 39, 5177-5182.

Kim, J., Kang, J.H., Park, H., Baek, S.Y., Kim, Y.H., Chang, Y.S., 2012. Assessment of polybrominated diphenyl ethers (PBDEs) in serum from the Korean general population. Environ. Pollut. 164, 46-52.

Kunisue, T., Takayanagi, N., Isobe, T., Takahashi, S., Nose, M., Yamada, T., Komori, H., Arita, N., Ueda, N., Tanabe, S., 2007. Polybrominated diphenyl ethers and persistent organochlorines in Japanese human adipose tissues. Environ. Int. 33, 1048-1056.

Law, R.J., Alaee, M., Allchin, C.R., Boon, J.P., Lebeuf, M., Lepom, P., Stern, G.A., 2003. Levels and trends of polybrominated diphenylethers and other brominated flame retardants in wildlife. Environ. Int. 29, 757-770.

Law, R., Allchin, C., De Boer, J., Covaci, A., Herzke, D., Lepom, P., 2006. Levels and trends of brominated flame retardants in the European environment. Chemosphere 64, 187-208.

Liang, S.X., Zhao, Q., Qin, Z.F., Zhao, X.R., Yang, Z.Z., Xu, X.B., 2008. Levels and distribution of polybrominated diphenyl ethers in various tissues of foraging hens from an electronic waste recycling area in South China. Environ. Toxicol. Chem. 27, 1279-1283.

Liang, X.W., Zhu, S.Z., Chen, P., Zhu, L.Y., 2010. Bioaccumulation and bioavailability of polybrominated diphynel ethers (PBDEs) in soil. Environ. Pollut. 158, 23872392.

Liu, P.Y., Du, G.D., Zhao, Y.X., Mu, Y.S., Zhang, A.Q., Qin, Z.F., Zhang, X.Y., Yan, S.S., Li, Y., Wei, R.G., Qin, X.F., Yang, Y.J., 2011. Bioaccumulation, maternal transfer and elimination of polybrominated diphenyl ethers in wild frogs. Chemosphere 84, 972-978.

Luo, Q., Cai, Z.W., Wong, M.H., 2007. Polybrominated diphenyl ethers in fish and sediment from river polluted by electronic waste. Sci. Total Environ. 383, 115127.

Malarvannan, G., Dirinck, E., Dirtu, A.C., Pereira-Fernandes, A., Neels, H., Jorens, P.G., Gaal, L.V., Blust, R., Covaci, A., 2013. Distribution of persistent organic pollutants in two different fat compartments from obese individuals. Environ. Int. 55, 3342.

McDonald, T.A., 2002. A perspective on the potential health risks of PBDEs. Chemosphere 46, 745-755.

McGraw, J.E., Waller, D.P., 2009. Fish ingestion and congener specific polychlorinated biphenyl and p, p'-dichlorodiphenyldichloroethylene serum concentrations in a great lakes cohort of pregnant African American women. Environ. Int. 35, 557-565.

Mühlebach, S., Bickel, M.H., 1981. Pharmacokinetics in rats of $2,4,5,2^{\prime}, 4^{\prime}, 5^{\prime}$, hexachlorobiphenyl, an unmetabolizable lipophilic model compound. Xenobiotica 11, 249-257.

Muir, D.C.G., Backus, S., Derocher, A.E., Dietz, R., Evans, T.J., Gabrielsen, G.W., Nagy, J., Norstrom, R.J., Sonne, C., Stirling, I., Taylor, M.K., Letcher, R.J., 2006. Brominated flame retardants in polar bears (Ursus maritimus) from Alaska, the Canadian Arctic, East Greenland, and Svalbard. Environ. Sci. Technol. 40, 449455.

Munoz-de-Toro, M., Beldomenico, H.R., Garcia, S.R., Stoker, C., De Jesus, J.J., Beldomenico, P.M., Ramos, J.G., Luque, E.H., 2006. Organochlorine levels in adipose tissue of women from a littoral region of Argentina. Environ. Res. 102. 107-112.

Munschy, C., Héas-Moisan, K., Tixier, C., Olivier, N., Gastineau, O., Le Bayon, N., Buchet, V., 2011. Dietary exposure of juvenile common sole (Solea solea L.) to polybrominated diphenyl ethers (PBDEs): Part 1. Bioaccumulation and elimination kinetics of individual congeners and their debrominated metabolites. Environ. Pollut. 159, 229-237.

Pulkrabová, J., Hrádková, P., Hajslová, J., Poustka, J., Nápravníková, M., Polácek, V., 2009. Brominated flame retardants and other organochlorine pollutants in human adipose tissue samples from the Czech Republic. Environ. Int. 35, 63-68.

Rahman, F., Langford, K.H., Scrimshaw, M.D., Lester, J.N., 2001. Polybrominated diphenyl ether (PBDE) flame retardants. Sci. Total Environ. 275, 1-17.

Rayne, S., Ikonomou, M.G., Ross, P.S., Ellis, G.M., Barrett-Lennard, L.G., 2004. PBDEs, PBBs, and PCNs in three communities of free-ranging killer whales
(Orcinus 298 orca) from the northeastern Pacific Ocean. Environ. Sci. Technol. 38, 4293-4299.

Riget, F., Vorkamp, K., Dietz, R., Rastogi, S.C., 2006. Temporal trend studies on 300 polybrominated diphenyl ethers (PBDEs) and polychlorinated biphenyls (PCBs) in ringed seals from East Greenland. J. Environ. Monit. 8, 1000-1005.

Ronald, K., Frank, R.J., Dougan, J.L., Frank, R., Braun, H.E., 1984. Pollutants in harp seals (Phoca groenlandica). I. Organochlorines. Sci. Total Environ. 38, 133-152.

Roszko, M., Obiedziński, M.W., Szymczyk, K., Rzepkowska, M., Szterk, A. Jędrzejczak, R., 2013. Seasonal and geographical variations in levels of polychlorinated biphenyls (PCB) and polybrominated diphenyl ethers (PBDE) in Polish butter fat used as an indicator of environmental contamination. Food Addit. Contam. Part A Chem. Anal. Control Expo. Risk Assess. 30, 181-201.

Sellstrom, U., Kierkegaard, A., Dewit, C., Jansson, B., 1998. Polybrominated diphenyl ethers and hexabromocyclododecane in sediments and fish from a Swedish river. Environ. Toxicol. Chem. 17, 1065-1072.

Staskal, D.F., Diliberto, J.J., DeVito, M.J., Birnbaum, L.S., 2005. Toxicokinetics of BDE 47 in female mice: effect of dose, route of exposure, and time. Toxicol. Sci. 83, $215-223$.

Thuresson, K., Höglund, P., Hagmar, L., Sjödin, A., Bergman, A., Jakobsson, K., 2006 Apparent half-lives of hepta- to decabrominated diphenyl ethers in human serum as determined in occupationally exposed workers. Environ. Health Perspect. 114, 176-181.

Tomy, G.T., Palace, V.P., Halldorson, T., Braekevelt, E., Danell, R., Wautier, K., Evans, B., Brinkworth, L., Fisk, A.T., 2004. Bioaccumulation, biotransformation, and biochemical effects of brominated diphenyl ethers in juvenile lake trout (Salvelinus namaycush). Environ. Sci. Technol. 38, 1496-1504.

Van den Steen, E., Jaspers, V.L., Covaci, A., Neels, H., Eens, M., Pinxten, R., 2009 Maternal transfer of organochlorines and brominated flame retardants in blue tits (Cyanistes caeruleus). Environ. Int. 35, 69-75.

Verreault, J., Letcher, R.J., Sonne, C., Dietz, R., 2009. Dietary, age and transgenerational effects on the fate of organohalogen contaminants in captive sledge dogs in Greenland. Environ. Int. 35, 56-62.

Vigano, L., Roscioli, C., Guzzella, L., 2011. Decabromodiphenyl ether (BDE-209) enters the food web of the River Po and is metabolically debrominated in resident cyprinid fishes. Sci. Total Environ. 409, 4966-4972.

Von Meyerinck, L., Hufnagel, B., Schmoldt, A., Benthe, H.F., 1990. Induction of rat liver microsomal cytochrome P-450 by the pentabromo diphenyl ether Bromkal 70 and half-lives of its components in the adipose tissue. Toxicology 61, 259274.

Voorspoels, S., Covaci, A., Lepom, P., Jaspers, V.L., Schepens, P., 2006. Levels and distribution of polybrominated diphenyl ethers in various tissues of birds of prey. Environ. Pollut. 14, 218-227.

Weijs, L., Dirtu, A.C., Das, K., Gheorghe, A., Reijnders, P.J.H., Neels, H., Blust, R. Covaci, A., 2009. Inter-species differences for polychlorinated biphenyls and polybrominated diphenyl ethers in marine top predators from the Southern North 318 Sea: Part 1. Accumulation patterns in harbour seals and harbour porpoises. Environ. Pollut. 157, 437-444.

Yang, Z.Z., Zhao, X.R., Zhao, Q., Qin, Z.F., Qin, X.F., Xu, X.B., Jin, Z.X., Xu, C.X., 2008 Polybrominated diphenyl ethers in leaves and soil from typical electronic waste polluted area in South China. Bull. Environ. Contam. Toxicol. 80, 340 344.

Yogui, G.T., Sericano, J.L., 2009. Polybrominated diphenyl ether flame retardants in the US marine environment: a review. Environ. Int. 35, 655-666.

Zhang, K., Wan, Y., Giesy, J.P., Lam, M.H.W., Wiseman, S., Jones, P.D., Hu, J., 2010 Tissue concentrations of polybrominated compounds in Chinese sturgeon (Acipenser sinensis): origin, hepatic sequestration, and maternal transfer Environ. Sci. Technol. 44, 5781-5786.

Zhang, W., Cai, Y., Sheng, G., Chen, D., Fu, J., 2011. Tissue distribution of decabrominated diphenyl ether (BDE-209) and its metabolites in sucking rat pups after prenatal and/or postnatal exposure. Toxicology 283, 49-54.

Zhao, Y.X., Qin, X.F., Li, Y., Liu, P.Y., Tian, M., Yan, S.S., Qin, Z.F., Xu, X.B., Yang, Y.J. 2009. Diffusion of polybrominated diphenyl ether (PBDE) from an e-waste recycling area to the surrounding regions in Southeast China. Chemosphere 76, $1470-1476$. 